\title{
UPAYA MENINGKATKAN KEMAMPUAN KOGNITIF ANAK MELALUI PERMAINAN SAINS
}

\author{
Endang Wahyuni \\ TK Tunas Harapan Palopo \\ Email: wahyuniendang932@gmail.com \\ Orcid Id: https://orcid.org/0000-0002-5023-9648
}

$\begin{array}{ll}\text { Article received } & : 2020-12-13 \\ \text { Review process } & : 2020-12-14 \\ \text { Article published } & : 2021-06-04\end{array}$

\begin{abstract}
The research objective was to determine how the efforts to improve children's cognitive abilities through science games in Group B TK Tunas Harapan Kota Palopo. This type of research in this study is a type of Classroom Action Research (PTK). Classroom Action Research carried out four stages of planning (planning); Action or action (acting); Observation (observing: Reflection). The research location of TK Tunas Harapan was located on Jl Benteng Raya, Benteng, Kec. Wara Timur, Palopo City, South Sulawesi Province. Data analysis techniques were carried out to obtain the average and percentage of children's cognitive abilities towards science games The results of the study, as a whole the results of the students' acquisition show that trying and telling about what happened $75 \%$ are declared Completed, while revealing cause and effect $59 \%$ are declared Not Completed and revealing the origin of something happening 68\% are declared Not Completed. due to the increase in the average cycle I to Cycle II of 50\%. Through games of science can improve children's cognitive abilities in Group B Kindergarten Tunas Harapan Palopo City.
\end{abstract}

Keywords: Cognitive, Game, Science.

\begin{abstract}
Abstrak
Tujuan penelitian untuk mengetahui bagaimana upaya meningkatkan kemampuan kognitif anak melalui permainan sains pada kelompok B TK Tunas Harapan Kota Palopo. Jenis penelitian pada penelitian ini adalah jenis Penelitian Tindakan Kelas (PTK). Penelitian Tindakan Kelas dilaksanakan empat tahap Perencanaan (planning); Aksi atau tindakan (acting); Observasi (observing: Refleksi (reflecting). Lokasi penelitian TK Tunas Harapan ini terletak di Jl Benteng Raya, Benteng, Kec. Wara Timur, Kota Palopo Prov. Sulawesi Selatan. Teknik analisis data dilakukan untuk memperoleh rata-rata dan persentase kemampuan kognitif anak terhadap permainan sains. Hasil penelitian, secara keseluruhan hasil perolehan peserta didik menunjukkan bahwa mencoba dan menceritakan tentang apa yang terjadi 75\% dinayatakan Sudah Tuntas, sementara mengungkapkan sebab akibat 59\% dinyatakan Belum Tuntas dan mengungkapkan asal mula terjadinya sesuatu 68\% dinyatakan Belum Tuntas. Hal ini disebabkan peningkatan rata-rata Siklus I ke Siklus II sebesar 50\%. Melalui Permainan Sains dapat Meningkatkan Kemampuan Kognitif Anak Pada Kelompok B TK Tunas Harapan Kota Palopo.
\end{abstract}

Kata Kunci: Kognitif, Permainan, Sains. 


\section{Pendahuluan}

Pendidikan anak usia dini adalah hal yang sangat penting dalam upaya pembinaan yang ditujukan pada anak usia dini yang mulai dari usia lahir sampai dengan usia enam tahun dengan tujuan memberikan rangsangan pendidikan mengenai pertumbuhan dan perkembangan anak dalam membentuk jasmani dan rohani agar ia kelak siap memasuki pendidikan lebih lanjut, hal ini tercermin dari Undang-Undang Republik Indonesia Nomor 20 Tahun 2003 Tentang Sistem Pendidikan Nasional Bab I Ketentuan Umum Pasal 1 Ayat 14 yang menjelaskan Pendidikan Anak Usia Dini. Pendidikan anak usia dini sesuai yang dijelaskan di atas bagian yang terpenting dalam mewujudkan pendidikan anak dalam memberikan stimulasi tumbuh dan kembang anak. Yusuf \& Sugandhi (2011) mengungkapan bahwa terdapat 5 aspek perkembangan anak yang harus dioptimalkan perkembangannya, anatara lain: perkembangan motorik, perkembangan bahasa, perkembangan kognitif, perkembangan sosial, perkembangan emosi, serta perkembangan kesadaran dalan beragama. Pada anak usia dini, perkembangan kognitif dilakukan secara bertahap, tidak bisa berkembang dengan pesat. Perkembangan kognitif pada anak usia dini sangat penting untuk dikembangankan karena akan berkaitan erat dengan kesiapan belajar anak di kemudian hari (Sujiono dalam Heri \& Ariana (2018).

Untuk memberikan stimulasi pada jalur pendidikan anak usia 5-6 tahun terutama di TK Tunas Harapan pada kegiatan pembelajaran tentu banyak hal tantangan yang di hadapi Guru Kelompok B, karena dengan keterbatasannya menyebabkan kemampuan perkembangan kognitif anak menjadi belum berkembang dengan sesuai harapan.

Kenyataan pembelajaran yang terjadi di atas dari hasil pengamatan pada tanggal 9 Desember 2019 pada pukul 07:30- 10:15 Wita bahwa kemampuan perkembangan kognitif anak dinyatakan belum berkembang sesuai harapan, hasilnya dari 17 peserta didikyang ada di Kelompok B, hanya ada lima orang anak yang menunjukkan mulai adanya perkembangan, sedangkan 12 orang anak lainnya masih kesulitan seperti mencoba dan menceritakan tentang apa yang terjadi pada gejala alam, adanya kesulitan dalam mengungkapkan sebab akibat gejala alam, kesulitan dalam mengungkapkan asal mula/terjadinya gejala alam. Berdasarkan data dari catatan anekdot juga ditemukan strategi atau metode yang diajarkan Guru Kelompok B terutama memberikan pembelajaran tidak menarik yang membuat anak jenuh. Ternyata RPPH yang dirancang belum sesuai dengan penerapannya seperti langkah-langkah kegiatan pembelajaran tidak terstruktur, tidak adanya media pembelajaran pada saat menjelaskan, kemudian hasil pekerjaan karya anak masih banyak yang belum sesuai dengan prosedur dalam kegiatan menanam sampai pada perawatannya.

Dari fakta di atas teridentifikasi bahwa a) kemampuan perkembangan kognitif belum berkembang sesuai dengan harapan; b) aktivitas masalah yang muncul terkait strategi, metode, dan media dalam mengajar tidak menarik; c) kemampuan faktor perkembangan kognitif anak dalam hasil pekerjaan karya peserta didikbelum sesuai yang diharapkan.

Untuk itu, masalah yang akan dipecahkan adalah pengembangan kemampuan perkembangan kognitif anak belum mendapatkan hasil sesuai harapan. Hal ini karena masalah tersebut paling berat dan dapat dikhawatirkan akan menimbulkan masalah baru pada perkembangan belajar selanjutnya. Maka dari itu, Guru Kelompok B diharapkan memiliki kemampuan dalam hal keterampilan yang lebih, sehingga pembelajaran lebih asik dan menyenangkan.

Untuk itu sangat dibutuhkan kegiatan pembelajaran yang dapat membuat suasana pembelajaran yang lebih asik dan menyenangkan melalui kegiatan permainan. Permainan adalah bagian yang sangat penting dalam sebuah pembelajaran, karena dengan bermain 
peserta didik banyak belajar melalui aktivitas yang mereka lakukan, mereka banyak mencari tahu dan lebih penasaran.

Salah satu permainan yang dapat mengembangkan kemampuan perkembangan kognitif anak adalah Permainan Sains. Permainan Sains adalah sebuah kegiatan bermain yang dapat membuat peserta didikmerasa senang dan dapat membuat anak tertarik dalam kegiatan aktivitas pada Permainan Sains. Permainan sains dapat membantu anak untuk melatih kemampuan berpikir kreatif, berpiki kritis, serta mempelajari berbagai konsep yang sederhana (Yulianti dalam Astuti (2014). Pembelajaran sains bagi anak memiliki peran yang penting untuk mengembangkan aspek kognitif dan membantu anak untuk memiliki dasar kemampuan sebagai sumber penerus bangsa kelak. Ketika seseorang menyadari kehidupan manusia yang semakin dinamis, semakin kompleks ruang ringkupnya, berkembang pesat dan berubah-ubah secara terus menerus maka ia akan memberikan pembekalan pembelajaran sains kepada anak. Hakikat sains perlu dipelajari, ditekuni, dan dikaji (Solichah \& Setyowati, 2014).Olehnya itu, permainan sains sederhana yang dimaksud diantaranya mengenali matahari, mengenali cuaca, mengenal musim, bagaimana sendimen terbetuk, melihat awan dan keadaan cuaca. Aktivitas yang dapat dilakukan dengan cara pengamatan, kegiatan percobaan, dan kegiatan menyelidiki sesuatu hal dengan cara mencari dan menemukan jawaban yang ada di sekitar lingkungan TK Tunas Harapan.

Untuk meningkatkan kemampuan perkembangan kognitif anak dapat dilakukan dengan permainan sains sederhana, karena untuk meningkatkan kemampuan kognitif anak. Piaget dalam Sudjiono (2007) mengklasifikasikan perkembangan otak untuk berpikir dan mengembangkan kognitif dalam 4 tingkatan, yaitu tahapan sensoris-motorik, praoperasional, operasional konkrit, operasional formal. Melalui tahapan ini, mereka harus memiliki keterampilan dalam mengamati hal apa saja disekitarnya yang mengalami perubahan, melakukan perbandingan, percobaan sederhana, membuat klasifikasi, memperkirakan suatu hal, dan dapat membangun kreativitas serta inovasi dalam dirinya. Dari hal tersebut, untuk mencapai tujuan pembelajaran, khususnya mengembangkan kemampuan kognitif anak, khususnya di TK Tunas Harapan Kota Palopo mengalami kendala, maka dari itu peneliti lebih tertarik untuk melakukan penelitian.

\section{Metode}

Penelitian ini menerapkan jenis Penelitian Tindakan Kelas (PTK). Penelitian tindakan adalah strategi yang digunakan guru kelas dalam memecahkan masalah yang terjadi di dalam kelas. Menurut Wibawa (Taniredja, 2010:15) bahwa PTK adalah bagian yang terpenting yang mengangkat permasalahan secara aktual di lapangan yang guru hadapi. Selain itu juga dijelaskan Kurt Lewin (Taniredja, 2010:23) bahwa dalam melaksanakan PTK ada empat tahap yang dapat dilakukan yaitu: (1) Perencanaan (planning); (2) Aksi atau tindakan (acting);(3) Observasi (observing: (4) Refleksi (reflecting). $\mathrm{Ke} 4$ siklus tersebut dikembangkan dengan teknik 9 langkah yaitu: (1) Perencanaan (planning); (2) Aksi atau tindakan (acting);(3) Observasi (observing: (4) Refleksi (reflecting); (5) Perencanaan (planning); (6) Aksi atau tindakan (acting);(7) Observasi (observing: (8) Refleksi (reflecting) (9) Siklus selanjutnya. Apabila di akhir siklus dinyatakan belum berhasil, maka akan dilanjutkan pada siklus berikutnya sampai dinyatakan siklus itu berhasil.

Lokasi penelitian TK Tunas Harapan ini terletak di Jl Benteng Raya, Benteng, Kec. Wara Timur, Kota Palopo Prov. Sulawesi Selatan yang dilaksanakan pada tanggal 25-31 Oktober 2020. Sumber data pada penelitian ini adalah peserta didikTK Tunas Harapan dengan jenjang usia 5-6 tahun yang berjumlah 11 orang anak laki-laki dan 6 orang anak perempuan. Jadi secara keseluruhan peserta didikkelompok B berjumlah 17 orang anak 
didik. Teknik yang diterapkan dalam mengumpulkan data yaitu dengan cara ceklis, melalui catatan anekdot, hasil karya project. Ceklis yaitu pengumpulan data dengan cara pengamatan instrumen di ukur berdasarkan skala penelitian yaitu Belum Berkembang (BB), Mulai Berkembang (MB), Berkembang Sesuai Harapan (BSH), Berkembang Sangat Baik (BSB), Suminah, Enah, dkk. (2015). Catatan anakdot adalah teknik mengumpulkan data selama proses penelitian yang bertujuan memberi gambaran penelitian dan mendukung data-data penelitian. Hasil karya adalah hasil karya peserta didiksesuai dengan kemampuan yang dimilikinya dalam membuat suatu kegiatan. Dokumentasi adalah sebuah peristiwa yang telah berlalu, dapat berupa arsip, foto, video pembelajaran.

Teknik keabsahan data dapat dilakukan dengan cara menguji keabsahan data yang diperoleh. Untuk mengontrol dapat dilakukan pengontrolan validitas internal selama pembelajaran berlangsung dengan memperhatikan kesiapan anak, kebiasaan anak, tidak hadir anak, penggunaan instrumen. Teknik analisis data adalah sebuah teknik dalam mengelola data yang telah terkumpul. Teknik analisis data menggunakan data kuantitatif dan data kualitatif. Teknik analisis data dilakukan untuk mengetahui sejauh mana hasil penelitian. Sebagaimana disebutkan bahwa untuk memperoleh rata-rata dilakukan dengan cara mencari hasil penelitian. Data yang telah terkumpul diolah dengan mencari rata-rata Anas Sudijono (2008:81) sebagai berikut:

$$
\begin{array}{l|l}
M_{x}=\frac{\sum x}{N} & \begin{array}{l}
\text { Keterangan: } \\
M_{X}=\text { Mean yang dicari }
\end{array} \\
& \sum X=\text { Jumlah dari skor perolehan } \\
N=\text { Jumlah Skor Maksmal }
\end{array}
$$

Berdasarkan uraian di atas, adapun cara menentukan kategori skala capaian perkembangan anak dalam Mengembangkan Kemampuan Kognitif Anak Melalui Permainan Sains dapat dilakukan sebagai berikut:

\section{Diketahui:}

Skor tertinggi $(\mathrm{St})=$ Jumlah Butir Instrumen $\mathrm{x}$ Skor tertinggi skala penilaian

$$
\mathrm{St}=3 \times 4=12
$$

Skor tertinggi $(\mathrm{Sr})=$ Jumlah Butir Instrumen $\mathrm{x}$ Skor terendah skala penilaian

Rentang $=\mathrm{St}-\mathrm{Sr}$

$$
\mathrm{Sr}=3 \times 1=3
$$

Rentang $=12-3=9$

Panjang kelas $=$ Rentang $/$ jumlah skala

Panjang kelas $=9 / 4=2,25$

\section{Penyelesaian:}

Menyusun Tabel Skala Capaian Perkembangan Anak dalam Mengembangkan Kemampuan Kognitif Anak Melalui Permainan Sains. Adapun tabel Skala Capaian Perkembangan Anak dapat dilihat pada tabel berikut:

Tabel 1: Kategori Capaian Pembelajaran

\begin{tabular}{|c|l|}
\hline Interval & \multicolumn{1}{c|}{ Kategori } \\
\hline $3-5,25$ & Belum Berkembang (BB) \\
\hline $5,25-7,5$ & Mulai Berkembang (MB) \\
\hline $7,5-9,75$ & Berkembang Sesuai harapan (BSH) \\
\hline $9,75-12$ & Berkembang Sangat Baik (BSB) \\
\hline
\end{tabular}


Selanjutnya untuk menentukan persentase adapun perhitungan Purwanto (2006:102) sebagai berikut :

\begin{tabular}{|l|l|}
\hline$P=\frac{F}{N} X 100 \%$ & Keterangan: \\
& $P=$ Persentase \\
& $F=$ Skor yang diperoleh \\
& $N=$ Skor maksium \\
\hline
\end{tabular}

Tabel 2: Persentase Capaian Pembelajaran

\begin{tabular}{|c|l|}
\hline Interval & \multicolumn{1}{c|}{ Kategori } \\
\hline $0-20$ & Sangat Kurang \\
\hline $21-40$ & Kurang \\
\hline $41-60$ & Cukup \\
\hline $61-80$ & Baik \\
\hline $81-100$ & Sangat Baik \\
\hline
\end{tabular}

\section{Hasil dan Pembahasan}

Hasil penelitian ini bertujuan Untuk Mengetahui Bagaimana Upaya Meningkatkan Kemampuan Kognitif Anak Melalui Permainan Sains Pada Kelompok B TK Tunas Harapan Kota Palopo.

\section{Pra Siklus}

Hasil penelitian hari selasa tanggal 21 Januari 2020 dengan tema alam semesta dengan materi mengenali matahari. Pada pembukaan, dilakukan bernyanyi "matahariku", mengamati ciri-ciri matahari, berdiskusi tentang matahari, berdoa sebelum belajar, menggunakan kata tolong, terima kasih, dan maaf dalam setiap kesempatan yang tepat, mengenalkan kegiatan dan aturan yang digunakan bermain. Pada inti, menyiapkan bahan yang digunakan dalam percobaan, guru memberikan penjelasan singkat mengenai percobaan yang dilakukan, memberikan kesempatan kepada peserta didikuntuk mengamati, tanya jawab antara guru dan anak didik. Pada kegiatan penutup dilakukan kegiatan menanyakan perasaan selama hari ini, berdiskusi kegiatan apa saja yang sudah dimainkan hari ini, mainan apa yang paling disukai, bercerita pendek yang berisi pesan-pesan, menginformasikan kegiatan untuk esok hari, berdoa setelah belajar.

Hasil penelitian hari rabu tanggal 22 Januari 2020 dengan jumlah 17 orang peserta didikdengan tema alam semesta, pada kegiatan pembukaan, bernyanyi "cuaca", mengenali cuaca, berdiskusi tentang cuaca, berdoa sebelum belajar, menggunakan kata tolong, terima kasih, dan maaf dalam setiap kesempatan yang tepat, mengenalkan kegiatan dan aturan yang digunakan bermain. Pada inti, menyiapkan bahan yang digunakan dalam percobaan, guru memberikan penjelasan singkat mengenai percobaan yang dilakukan, memberikan kesempatan kepada peserta didikuntuk mengamati, tanya jawab antara guru dan anak didik. Pada kegiatan penutup, menanyakan perasaan selama hari ini, berdiskusi kegiatan apa saja yang sudah dimainkan hari ini, mainan apa yang paling disukai, bercerita pendek yang berisi pesan-pesan, menginformasikan kegiatan untuk esok hari, berdoa setelah belajar.

Hasil penelitian hari kamis tanggal 23 Januari 2020 dengan jumlah 17 orang peserta didikdengan tema alam semesta, materi mengenal musim, pada kegiatan pembukaan, bernyanyi "musim", mengenal musim salju, berdiskusi tentang musim, berdoa sebelum 
belajar, menggunakan kata tolong, terima kasih, dan maaf dalam setiap kesempatan yang tepat, mengenalkan kegiatan dan aturan yang digunakan bermain. Pada kegiatan inti, menyiapkan bahan yang digunakan dalam percobaan, guru memberikan penjelasan singkat mengenai percobaan yang dilakukan, memberikan kesempatan kepada peserta didikuntuk mengamati, tanya jawab antara guru dan anak didik. Bagian recalling, merapikan mainan, diskusi tentang perasaan diri selama melakukan kegiatan bermain, bila ada perilaku yang kurang tepat harus didiskusikan bersama, menceritakan dan menunjukkan hasil karyanya, penguatan pengetahuan yang didapat anak. Pada kegiatan penutup, menanyakan perasaan selama hari ini, berdiskusi kegiatan apa saja yang sudah dimainkan hari ini, mainan apa yang paling disukai, bercerita pendek yang berisi pesan-pesan, menginformasikan kegiatan untuk esok hari, berdoa setelah belajar.

Hasil pengamatan pada tanggal 9 Desember 2019 dengan jumlah 17 orang peserta didikpada pukul 07:30- 10:15 Wita bahwa kemampuan perkembangan kognitif anak dinyatakan belum berkembang sesuai harapan, hasilnya dari 17 peserta didikyang ada di Kelompok B, hanya ada lima orang anak yang menunjukkan mulai adanya perkembangan, sedengkan 12 orang anak lainnya masih kesulitan seperti mencoba dan menceritakan tentang apa yang terjadi pada gejala alam, adanya kesulitan dalam mengungkapkan sebab akibat gejala alam, kesulitan dalam mengungkapkan asal mula/terjadinya gejala alam. Secara keseluruhan peserta didikdiperoleh hasil penelitian sebesar $56 \%$ yang dinyatakan Belum Tuntas.

\section{Siklus I}

Hasil penelitian hari senin tanggal 26 oktober 2020 dengan tema alam semesta dengan materi mengenali matahari. Pada pembukaan, dilakukan bernyanyi "matahariku", mengamati ciri-ciri matahari, berdiskusi tentang matahari, berdoa sebelum belajar, menggunakan kata tolong, terima kasih, dan maaf dalam setiap kesempatan yang tepat, mengenalkan kegiatan dan aturan yang digunakan bermain. Pada inti, menyiapkan bahan yang digunakan dalam percobaan, guru memberikan penjelasan singkat mengenai percobaan yang dilakukan, memberikan kesempatan kepada peserta didikuntuk mengamati, tanya jawab antara guru dan anak didik. Pada recalling, merapikan mainan, diskusi tentang perasaan diri selama melakukan kegiatan bermain, bila ada perilaku yang kurang tepat harus didiskusikan bersama, menceritakan dan menunjukkan hasil karyanya, penguatan pengetahuan yang didapat anak. Pada kegiatan penutup dilakukan kegiatan menanyakan perasaan selama hari ini, berdiskusi kegiatan apa saja yang sudah dimainkan hari ini, mainan apa yang paling disukai, bercerita pendek yang berisi pesan-pesan, menginformasikan kegiatan untuk esok hari, berdoa setelah belajar.

Hasil penelitian hari senin tanggal 26 oktober 2020 dengan tema alam semesta, pada kegiatan pembukaan, bernyanyi "cuaca", mengenali cuaca, berdiskusi tentang cuaca, berdoa sebelum belajar, menggunakan kata tolong, terima kasih, dan maaf dalam setiap kesempatan yang tepat, mengenalkan kegiatan dan aturan yang digunakan bermain. Pada inti, menyiapkan bahan yang digunakan dalam percobaan, guru memberikan penjelasan singkat mengenai percobaan yang dilakukan, memberikan kesempatan kepada peserta didikuntuk mengamati, tanya jawab antara guru dan anak didik. Pada kegiatan recalling, merapikan mainan, diskusi tentang perasaan diri selama melakukan kegiatan bermain, bila ada perilaku yang kurang tepat harus didiskusikan bersama, menceritakan dan menunjukkan hasil karyanya, penguatan pengetahuan yang didapat anak. Pada kegiatan penutup, menanyakan perasaan selama hari ini, berdiskusi kegiatan apa saja yang sudah dimainkan hari ini, mainan 
apa yang paling disukai, bercerita pendek yang berisi pesan-pesan, menginformasikan kegiatan untuk esok hari, berdoa setelah belajar.

Hasil penelitian hari senin tanggal 27 oktober 2020 dengan tema alam semesta, materi mengenal musim, pada kegiatan pembukaan, bernyanyi "musim", mengenal musim salju, berdiskusi tentang musim, berdoa sebelum belajar, menggunakan kata tolong, terima kasih, dan maaf dalam setiap kesempatan yang tepat, mengenalkan kegiatan dan aturan yang digunakan bermain. Pada kegiatan inti, menyiapkan bahan yang digunakan dalam percobaan, guru memberikan penjelasan singkat mengenai percobaan yang dilakukan, memberikan kesempatan kepada peserta didikuntuk mengamati, tanya jawab antara guru dan anak didik. Bagian recalling, merapikan mainan, diskusi tentang perasaan diri selama melakukan kegiatan bermain, bila ada perilaku yang kurang tepat harus didiskusikan bersama, menceritakan dan menunjukkan hasil karyanya, penguatan pengetahuan yang didapat anak. Pada kegiatan penutup, menanyakan perasaan selama hari ini, berdiskusi kegiatan apa saja yang sudah dimainkan hari ini, mainan apa yang paling disukai, bercerita pendek yang berisi pesan-pesan, menginformasikan kegiatan untuk esok hari, berdoa setelah belajar.

Hasil penelitian Siklus I Untuk Mengetahui Bagaimana Upaya Meningkatkan Kemampuan Kognitif Anak Melalui Permainan Sains Pada Kelompok B TK Tunas Harapan Kota Palopo bahwa pada penelitian ini yang terlibat berjumlah 17 orang anak didik. Responden dengan Inisial A pada Siklus I memperoleh kemampuan kognitif anak melalui permainan sains sederhana dengan skor 7 dengan kriteria Mulai Berkembang dengan tingkat persentase sebesar 58\% dinyatakan Belum Tuntas dari $\geq 71 \%$. Responden dengan Inisial B pada Siklus I memperoleh kemampuan kognitif anak melalui permainan sains sederhana dengan skor 8 dengan kriteria Berkembang Sesuai Harapan dengan tingkat persentase sebesar $67 \%$ dinyatakan Belum Tuntas dari $\geq 71 \%$. Responden dengan Inisial C pada Siklus I memperoleh kemampuan kognitif anak melalui permainan sains sederhana dengan skor 8 dengan kriteria Berkembang Sesuai Harapan dengan tingkat persentase sebesar 67\% dinyatakan Belum Tuntas dari $\geq 71 \%$. Responden dengan Inisial D pada Siklus I memperoleh kemampuan kognitif anak melalui permainan sains sederhana dengan skor 8 dengan kriteria Berkembang Sesuai Harapan dengan tingkat persentase sebesar $67 \%$ dinyatakan Belum Tuntas dari $\geq 71 \%$.

Responden dengan Inisial E pada Siklus I memperoleh kemampuan kognitif anak melalui permainan sains sederhana dengan skor 9 dengan kriteria Berkembang Sesuai Harapan dengan tingkat persentase sebesar $75 \%$ dinyatakan Sudah mencapaidari $\geq 71 \%$. Responden dengan Inisial F pada Siklus I memperoleh kemampuan kognitif anak melalui permainan sains sederhana dengan skor 8 dengan kriteria Berkembang Sesuai Harapan dengan tingkat persentase sebesar $67 \%$ dinyatakan Belum Tuntas dari $\geq 71 \%$. Responden dengan Inisial $\mathrm{G}$ pada Siklus I memperoleh kemampuan kognitif anak melalui permainan sains sederhana dengan skor 8 dengan kriteria Berkembang Sesuai Harapan dengan tingkat persentase sebesar $67 \%$ dinyatakan Belum Tuntas dari $\geq 71 \%$. Responden dengan Inisial $\mathrm{H}$ pada Siklus I memperoleh kemampuan kognitif anak melalui permainan sains sederhana dengan skor 9 dengan kriteria Berkembang Sesuai Harapan dengan tingkat persentase sebesar $75 \%$ dinyatakan Sudah mencapaidari $\geq 71 \%$.

Responden dengan Inisial I pada Siklus I memperoleh kemampuan kognitif anak melalui permainan sains sederhana dengan skor 7 dengan kriteria Mulai Berkembang dengan tingkat persentase sebesar $58 \%$ dinyatakan Belum Tuntas dari $\geq 71 \%$. Responden dengan Inisial $\mathbf{J}$ pada Siklus I memperoleh kemampuan kognitif anak melalui permainan sains sederhana dengan skor 10 dengan kriteria Berkembang Sangat Baik dengan tingkat 
persentase sebesar $83 \%$ dinyatakan Sudah Tuntas dari $\geq 71 \%$. Responden dengan Inisial K pada Siklus I memperoleh kemampuan kognitif anak melalui permainan sains sederhana dengan skor 7 dengan kriteria Mulai Berkembang dengan tingkat persentase sebesar $58 \%$ dinyatakan belum mencapai dari $\geq 71 \%$.

Responden dengan Inisial L pada Siklus I memperoleh kemampuan kognitif anak melalui permainan sains sederhana dengan skor 7 dengan kriteria Mulai Berkembang dengan tingkat persentase sebesar $58 \%$ dinyatakan Belum Tuntas dari $\geq 71 \%$. Responden dengan Inisial M pada Siklus I memperoleh kemampuan kognitif anak melalui permainan sains sederhana dengan skor 8 dengan kriteria Berkembang Sesuai Harapan dengan tingkat persentase sebesar $67 \%$ dinyatakan Belum Tuntas dari $\geq 71 \%$. Responden dengan Inisial N pada Siklus I memperoleh kemampuan kognitif anak melalui permainan sains sederhana dengan skor 8 dengan kriteria Berkembang Sesuai Harapan dengan tingkat persentase sebesar $67 \%$ dinyatakan Belum Tuntas dari $\geq 71 \%$. Responden dengan Inisial O pada Siklus I memperoleh kemampuan kognitif anak melalui permainan sains sederhana dengan skor 8 dengan kriteria Berkembang Sesuai Harapan dengan tingkat persentase sebesar 67\% dinyatakan Belum Tuntas dari $\geq 71 \%$.

Responden dengan Inisial P pada Siklus I memperoleh kemampuan kognitif anak melalui permainan sains sederhana dengan skor 8 dengan kriteria Berkembang Sesuai Harapan dengan tingkat persentase sebesar $67 \%$ dinyatakan Belum Tuntas dari $\geq 71 \%$. Responden dengan Inisial Q pada Siklus I memperoleh kemampuan kognitif anak melalui permainan sains sederhana dengan skor 9 dengan kriteria Berkembang Sesuai Harapan dengan tingkat persentase sebesar $75 \%$ dinyatakan sudah mencapai dari $\geq 71 \%$.

\section{Siklus II}

Hasil penelitian hari senin tanggal 28 Oktober 2020 dengan tema alam semesta, materi mengenali matahari. Pada kegiatan pembukaan, bernyanyi "matahariku", mengamati ciriciri matahari, berdiskusi tentang matahari, berdoa sebelum belajar, menggunakan kata tolong, terima kasih, dan maaf dalam setiap kesempatan yang tepat, mengenalkan kegiatan dan aturan yang digunakan bermain. Pada kegiatan inti, menyiapkan bahan yang digunakan dalam percobaan yaitu bola dan senter, guru memberikan penjelasan singkat mengenai percobaan yang dilakukan, guru memperlihatkan percobaan sains yaitu guru menyalakan senter dan mengarahkan pada bola, memberikan kesempatan kepada peserta didikuntuk mengamati bola yang diberikan cahaya lampu senter kemudian mempraktekkan, tanya jawab antara guru dan anak didik. Pada kegiatan recalling, merapikan mainan, diskusi tentang perasaan diri selama melakukan kegiatan bermain, bila ada perilaku yang kurang tepat harus didiskusikan bersama, menceritakan dan menunjukkan hasil karyanya, penguatan pengetahuan yang didapat anak. Bagian penutup, menanyakan perasaan selama hari ini, berdiskusi kegiatan mengamati bola yang diberikan cahaya lampu senter yang sudah dimainkan hari ini, mainan apa yang paling disukai, bercerita pendek yang berisi pesanpesan, menginformasikan kegiatan untuk esok hari, berdoa setelah belajar.

Hasil penelitian hari senin tanggal 29 Oktober 2020 dengan jumlah 17 orang peserta didikdilakukan kegiatan penelitian dengan tema alam semesta, materi mengenali cuaca, kegiatan pembukaan, bernyanyi "cuaca", berdiskusi tentang cuaca, berdoa sebelum belajar, menggunakan kata tolong, terima kasih, dan maaf dalam setiap kesempatan yang tepat, mengenalkan kegiatan dan aturan yang digunakan bermain. Pada bagain inti, menyiapkan bahan yang digunakan dalam percobaan yaitu toples bening, air, pewarna, busa, guru memberikan percobaan, menyiapkan toples, isi toples dengan air, masukkan busa ke dalam toples, teteskan perwarna makanan pada busa, memberikan kesempatan kepada peserta 
didikuntuk mengamati, tanya jawab antara guru dan peserta didiktentang percobaan yang dilakukan. Pada kegiatan recalling, merapikan mainan, diskusi tentang perasaan diri selama melakukan kegiatan bermain, bila ada perilaku yang kurang tepat harus didiskusikan bersama, menceritakan dan menunjukkan hasil karyanya, penguatan pengetahuan yang didapat anak. Pada kegiatan penutup menanyakan perasaan selama hari ini, berdiskusi kegiatan apa saja yang sudah diamati hari ini, bercerita pendek yang berisi pesan-pesan dan menginformasikan kegiatan untuk esok hari, berdoa setelah belajar.

Hasil penelitian hari senin tanggal 30 Oktober 2020 dengan tema alam semesta, materi mengenal musim dengan alat dan bahan main yang dibutuhkan kipas dan butiran styrofoam. Pada kegiatan pembuka bernyanyi "musim", mengenal musim salju, berdiskusi tentang musim, berdoa sebelum belajar, menggunakan kata tolong, terima kasih, dan maaf dalam setiap kesempatan yang tepat, mengenalkan kegiatan dan aturan yang digunakan bermain. Pada kegiatan inti, menyiapkan bahan yang digunakan dalam percobaan, kipas dan butiran styrofoam, guru menyalakan kipas dan menaburkan butiran styrofoam di depan kipas angin, memberikan kesempatan 17 orang peserta didikuntuk mengamati, tanya jawab antara guru dan anak didik. Pada kegiatan recalling, merapikan mainan, diskusi tentang perasaan diri selama melakukan kegiatan bermain, bila ada perilaku yang kurang tepat harus didiskusikan bersama, menceritakan dan menunjukkan hasil karyanya, penguatan pengetahuan yang didapat anak. Pada kegiatan penutup menanyakan perasaan selama hari ini, berdiskusi kegiatan apa saja yang sudah dimainkan hari ini, mainan apa yang paling disukai, bercerita pendek yang berisi pesan-pesan, menginformasikan kegiatan untuk esok hari, berdoa setelah belajar.

Hasil penelitian Siklus II Untuk Mengetahui Bagaimana Upaya Meningkatkan Kemampuan Kognitif Anak Melalui Permainan Sains Pada Kelompok B TK Tunas Harapan Kota Palopo bahwa responden dengan Inisial A pada Siklus I memperoleh kemampuan kognitif anak melalui permainan sains sederhana dengan skor 11 dengan kriteria Berkembang Sangat Baik dengan tingkat persentase sebesar 92\% dinyatakan sudah mencapai dari $\geq 71 \%$. Responden dengan Inisial B pada Siklus I memperoleh kemampuan kognitif anak melalui permainan sains sederhana dengan skor 12 dengan kriteria Berkembang Sangat Baik dengan tingkat persentase sebesar 100\% dinyatakan sudah mencapai dari $\geq 71 \%$. Responden dengan Inisial C pada Siklus I memperoleh kemampuan kognitif anak melalui permainan sains sederhana dengan skor 11 dengan kriteria Berkembang Sangat Baik dengan tingkat persentase sebesar 92\% dinyatakan sudah mencapai dari $\geq 71 \%$. Responden dengan Inisial D pada Siklus I memperoleh kemampuan kognitif anak melalui permainan sains sederhana dengan skor 12 dengan kriteria Berkembang Sangat Baik dengan tingkat persentase sebesar 100\% dinyatakan sudah mencapai dari $\geq 71 \%$.

Responden dengan Inisial E pada Siklus I memperoleh kemampuan kognitif anak melalui permainan sains sederhana dengan skor 11 dengan kriteria Berkembang Sangat Baik dengan tingkat persentase sebesar $92 \%$ dinyatakan Sudah mencapai dari $\geq 71 \%$. Responden dengan Inisial F pada Siklus I memperoleh kemampuan kognitif anak melalui permainan sains sederhana dengan skor 11 dengan kriteria Berkembang Sangat Baik dengan tingkat persentase sebesar 92\% dinyatakan Sudah mencapaidari $\geq 71 \%$. Responden dengan Inisial G pada Siklus I memperoleh kemampuan kognitif anak melalui permainan sains sederhana dengan skor 11 dengan kriteria Berkembang Sangat Baik dengan tingkat persentase sebesar $92 \%$ dinyatakan Sudah mencapaidari $\geq 71 \%$. Responden dengan Inisial H pada Siklus I memperoleh kemampuan kognitif anak melalui permainan sains sederhana dengan skor 12 
dengan kriteria Berkembang Sangat Baik dengan tingkat persentase sebesar $100 \%$ dinyatakan Sudah mencapaidari $\geq 71 \%$.

Responden dengan Inisial I pada Siklus I memperoleh kemampuan kognitif anak melalui permainan sains sederhana dengan skor 9 dengan kriteria Berkembang Sesuai Harapan dengan tingkat persentase sebesar $75 \%$ dinyatakan Sudah mencapaidari $\geq 71 \%$. Responden dengan Inisial J pada Siklus I memperoleh kemampuan kognitif anak melalui permainan sains sederhana dengan skor 11 dengan kriteria Berkembang Sangat Baik dengan tingkat persentase sebesar 92\% dinyatakan Sudah mencapaidari $\geq 71 \%$. Responden dengan Inisial K pada Siklus I memperoleh kemampuan kognitif anak melalui permainan sains sederhana dengan skor 11 dengan kriteria Berkembang Sangat Baik dengan tingkat persentase sebesar 92\% dinyatakan Sudah mencapaidari $\geq 71 \%$.

Responden dengan Inisial L pada Siklus I memperoleh kemampuan kognitif anak melalui permainan sains sederhana dengan skor 11 dengan kriteria Berkembang Sangat Baik dengan tingkat persentase sebesar 92\% dinyatakan Sudah mencapaidari $\geq 71 \%$. Responden dengan Inisial M pada Siklus I memperoleh kemampuan kognitif anak melalui permainan sains sederhana dengan skor 11 dengan kriteria Berkembang Sangat Baik dengan tingkat persentase sebesar 92\% dinyatakan Sudah mencapaidari $\geq 71 \%$. Responden dengan Inisial N pada Siklus I memperoleh kemampuan kognitif anak melalui permainan sains sederhana dengan skor 11 dengan kriteria Berkembang Sangat Baik dengan tingkat persentase sebesar $92 \%$ dinyatakan Sudah mencapaidari $\geq 71 \%$. Responden dengan Inisial O pada Siklus Imemperoleh kemampuan kognitif anak melalui permainan sains sederhana dengan skor 11 dengan kriteria Berkembang Sangat Baik dengan tingkat persentase sebesar 92\% dinyatakan Sudah mencapai dari $\geq 71 \%$.

Responden dengan Inisial pada Siklus I memperoleh kemampuan kognitif anak melalui permainan sains sederhana dengan skor 11 dengan kriteria Berkembang Sangat Baik dengan tingkat persentase sebesar 92\% dinyatakan Sudah mencapaidari $\geq 71 \%$. Responden dengan Inisial Q pada Siklus I memperoleh kemampuan kognitif anak melalui permainan sains sederhana dengan skor 10 dengan kriteria Berkembang Sangat Baik dengan tingkat persentase sebesar $83 \%$ dinyatakan Sudah mencapaidari $\geq 71 \%$.

Secara keseluruhan kegiatan permainan sains yang dapat dilakukan pada anak usia dini usia 5-6 tahun yaitu Mengenali Matahari, Mengenali cuaca, Mengenal musim, Bagaimana sendimen terbentuk, Melihat awan dan keadaan cuaca. Penelitian ini menggunakan jenis penelitian PTK yaitu: (1) Perencanaan (planning); (2) Aksi atau tindakan (acting);(3) Observasi (observing: (4) Refleksi (reflecting). Penelitian ini dilaksanakn dua siklus. Adapun hasil persentase Kemampuan Kognitif Anak Melalui Permainan Sains Pada Kelompok B TK Tunas Harapan Kota Palopo sebegai berikut:

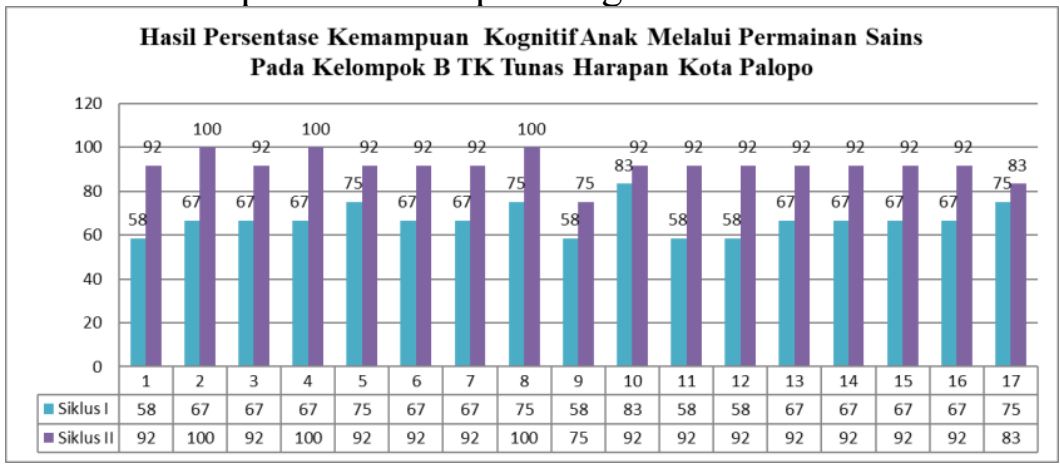

Gambar 1: Hasil Persentasi Kemampuan Kognitif Anak

Berdasarkan tabel di atas, maka hasil indikator secara keseluruhan hasil perolehan peserta didikmenunjukkan bahwa mencoba dan menceritakan tentang apa yang terjadi $75 \%$ 
dinayatakan Sudah Tuntas, mengungkapkan sebab akibat 59\% dinyatakan Belum Tuntas, Mengungkapkan asal mula/terjadinya sesuatu 68\% dinyatakan Belum Tuntas. Oleh karena mengalami peningkatan rata-rata Siklus I ke Siklus II sebesar 50\%. Dengan demikian Melalui Permainan Sains Pada Kelompok B TK Tunas Harapan Kota Palopo dapat Meningkatkan Kemampuan Kognitif Anak. Berikut tabel peningkatan sebagai nerikut:

Tabel 3 : Peningkatan Penelitian Siklus I ke Siklus II

\begin{tabular}{|c|c|c|c|}
\hline Keterangan & Siklus I & Siklus II & Peningkatan \\
\hline Jumlah & 137 & 187 & 50 \\
\hline Rata-rata & 8 & 11 & 3 \\
\hline Kriteria & BSH & BSB & \\
\hline Persentase & 67 & 92 & 25 \\
\hline$\geq 71 \%$ & $\begin{array}{c}\text { Belum } \\
\text { Tuntas }\end{array}$ & $\begin{array}{c}\text { Sudah } \\
\text { Tuntas }\end{array}$ \\
\hline
\end{tabular}

Berdasarkan hal tersebut bahwa permainan sains dapat membantu anak untuk melatih kemampuan berpikir kreatif, berpiki kritis, serta mempelajari berbagai konsep yang sederhana (Yulianti dalam Astuti (2014). Pembelajaran sains bagi anak memiliki peran yang penting untuk mengembangkan aspek kognitif dan membantu anak untuk memiliki dasar kemampuan sebagai sumber penerus bangsa kelak. Ketika seseorang menyadari kehidupan manusia yang semakin dinamis, semakin kompleks ruang ringkupnya, berkembang pesat dan berubah-ubah secara terus menerus maka ia akan memberikan pembekalan pembelajaran sains kepada anak. Hakikat sains perlu dipelajari, ditekuni, dan dikaji (Solichah \& Setyowati, 2014). Maka dapat disimpulkan Melalui Permainan Sains dapat Meningkatkan Kemampuan Kognitif Anak Pada Kelompok B TK Tunas Harapan Kota Palopo.

\section{Simpulan}

Berdasarkan hasil dari penelitian, maka disusunlah simpulan penelitian ini yaitu Secara keseluruhan hasil perolehan peserta didikmenunjukkan bahwa mencoba dan menceritakan tentang apa yang terjadi pada siklus I rata-rata mencapai skor 8 yang berarti bahwa dari 11 orang peserta didikdinyatakan berkembang sesuai harapan namun, hasil persentase sebesar $67 \%$ yang artinya dinyatakan belum mencapai ketuntasan $71 \%$. pada siklus II rata-rata mencapai skor 11 yang berarti bahwa dari 11 orang peserta didikdinyatakan berkembang sangat baik namun, hasil persentase sebesar $92 \%$ yang artinya dinyatakan sudah mencapai ketuntasan 71\%. Bardasarkan hal tersebut mengalami peningkatan dari siklus I ke siklus II sebesar 25\%. Ini artinya bahwa dapat disimpulkan Melalui Permainan Sains dapat Meningkatkan Kemampuan Kognitif Anak Pada Kelompok B TK Tunas Harapan Kota Palopo.

\section{Daftar Rujukan}

Astuti, Y. D. 2014. Metode Permainan Sains Berpengaruh Terhadap Kemampuan Kognitif Anak Kelompok A BA Asyiyah Meger Ceper Klaten Tahun Ajaran 2014/2015. Naskah Publikasi Universitas Muhammadiyah Surakarta, 1-8.

Heri, M dan Ariana. 2018. Judul Pengaruh Media Flashcard terhadap kemampuan kognitif anak di TK Pantisila PAUD Singaraja. Jurnal Kesehatan Midwinerslion, II(2), 221227. 
Ngalim, Purwanto. 2009. Evaluasi Pengajaran. Bandung: PT Remaja Rosdakarya.

Solichah, L., \& Setyowati, S. 2014. Meningkatkan Kemampuan Kognitif Anak Dengan Metode Eksperimen Melalui Permainan Sains Kelompok B Tk Hang Tuah 10 Sidoarjo. PAUD Terarat (Jurnal Ilmiah Pendidikan Anak Usia Dini), III(1), 1-5.

Sudijono, Anas. 2008. Pengantar Statistik Pendidikan. Jakarta: PT Raja Grafindo Persada.

Sudjiono, Y. 2007. Metode Pengembangan Kognitif. Jakarta: Universitas Terbuka.

Taniredja, Tukiran dkk. 2010. Penelitian Tindakan Kelas. Bandung: Alfabeta.

Yusuf, S., \& Sugandhi, M. 2011. Perkembangan Peserta Didik Edisi 1. Jakarta: Rajawali Pers. 